A N N A L E S

UNIVERSITATIS MARIAE CURIE-SKŁODOWSKA

LUBLIN - POLONIA

VOL. LXVI, 1

SECTIO G

2019

Uniwersytet Marii Curie-Skłodowskiej w Lublinie

MAŁGORZATA ŁUSZCZYŃSKA

m.luszczynska@poczta.umcs.lublin.pl

ORCID: 0000-0002-4387-8820

\title{
Na straży ordo. Hierarchiczne uporządkowanie życia społecznego w myśli wieków średnich
}

Hierarchical Structure of the Social Life in Thought of the Middle Ages

Średniowiecze, najdłuższa epoka w dziejach ludzkości, w odniesieniu do poszczególnych zagadnień życia społecznego prezentowało całą mozaikę rozmaitych koncepcji. Taki stan rzeczy był uwarunkowany ewolucją poszczególnych idei. $\mathrm{Na}$ tle wielu zmiennych jedynym punktem constans wydaje się co do zasady problematyka ładu i porządku. Ordo nierozerwalnie wiąże się ze strukturą społeczną, ius aeterna, koncepcją dobra wspólnego (w imię którego część podporządkowana jest całości), organiczną koncepcją państwa czy pochodzeniem władzy politycznej.

Człowiek jest tworem Boga, pielgrzymem idącym przez świat doczesny do ojczyzny niebieskiej. Dąży do stworzenia sobie właściwych warunków umożliwiających realizację głównego celu jego egzystencji - wytyczenia drogi wiodącej ku zbawieniu. Porządek doczesny to „dzieło i odblask Boga”1. „Ten realny świat został stworzony przez Boga, dlatego też to wszystko, co w nim istnieje, łączy się w porządku hierarchicznym prowadzącym do Boga (ordo ad Deum)"2.

Hierarchia jest warunkiem ładu i porządku społecznego przez trwanie jednostek na właściwych dla nich miejscach. „Obowiązkiem średniowiecznego człowieka było zostać tam, gdzie Bóg go postawił”’3. Kto przeciwstawiał się boskiemu planowi urządzenia świata, ten grzeszył pychą lub hańbił się poniżaniem.

\footnotetext{
W. Kornatowski, Spoleczno-polityczna myśl św. Augustyna, Warszawa 1965, s. 31.

2 M. Sadowski, Godność człowieka i dobro wspólne w papieskim nauczaniu społecznym (1878-2005), Wrocław 2010, s. 88.

3 J. Le Goff, Człowiek średniowiecza, [w:] Człowiek średniowiecza, red. J. Le Goff, Warszawa 2000, s. 49.
} 
Zagadnienie ordo nierozerwalnie wiąże się z myślą wieków średnich, poczynając od doktryny św. Augustyna, na schyłkowym okresie działalności św. Tomasza z Akwinu kończąc. To kwintesencja myśli mediewistycznej. Bez ordo, opartego na hierarchicznym podporządkowaniu, nie ma pokoju, sprawiedliwości oraz poczucia stabilności życia politycznego ${ }^{4}$.

Desygnat pojęciowy ordo można zatem określić jako „uporządkowaną zgodę"5. Problematyka ordo kształtuje się dwutorowo: jako gradacja stanowa uwarunkowana głównie podziałem pracy oraz jako ordo universalis, czyli porządek jako taki, uporządkowanie prowadzące wprost do hierarchii bytów stworzonych przez Boga.

Stworzenia mniej szlachetne istnieją dla szlachetniejszych, tak jak stworzenia znajdujące się poniżej człowieka istnieją dla człowieka. Zatem - pojedyncze stworzenia istnieją dla doskonałości całego wszechświata. A dalej - cały wszechświat, wraz z poszczególnymi swymi częściami, jest ukierunkowany ku Bogu jako swemu celowi tym bardziej, im bardziej w poszczególnych częściach jest w pewien sposób odwzorowana Boża dobroć na chwałę Boga. Nie przeszkadza to zaś, że ponadto stworzenia rozumne mają Boga za cel w szczególny sposób, gdyż mogą do Niego dojść przez swoje działanie: poznając i kochając ${ }^{6}$.

$\mathrm{Na}$ czele wszelkiego stworzenia stoi człowiek - pars principalis universi byt rozumny, posiadający z racji swojego intelektu władztwo nad światem stworzonym przez Boga. Przez fakt naturale dominium staje się substytutem Boga, kimś na kształt Dei cooperator.

W VI w. Dionizy Areopagita drobiazgowo opisał w swoich dziełach hierarchię aniołów i odwzorowany na jej przykładzie porządek społeczny. Hierarchia ludzka jest bowiem odpowiednikiem hierarchii niebieskiej (chóry anielskie, święci i błogosławieni) oraz hierarchii kościelnej (papież, kardynałowie, biskupi itd.). Pojęcie porządku zakłada uszeregowanie w kolejności według ustalonego kryterium. Kolejność wytyczają stopnie przyszeregowania, gdzie jeden następuje po drugim. Pojawia się zatem kwestia pierwszeństwa i następstwa, zagadnienie stosunku do tego, co pierwotne oraz do tego, co wtórne. Porządek jest tam, gdzie jest początek i jego następstwa uszeregowane w kolejności następowania po sobie.

W XII i XIII w. obok „hierarchii pionowej” zaczęto wyróżniać „hierarchię poziomą”. Tomasz z Akwinu w każdej społeczności politycznej wyróżnił „,poczwórny porządek i układ": pierwszy - między podmiotem sprawującym władzę a jego podwładnymi; drugi - „podwładni między sobą”; trzeci - „należący do narodu i obce narody”; czwarty - „układ domowy: ojciec - syn, żona - mąż, pan - niewolnik, służba"”. O ile pierwszy i ostatni rodzaj uporządkowania można ująć

4 M. Sadowski, op. cit., s. 89.

Św. Augustyn, Państwo Boże, Kęty 1999, s. 779-780.

Św. Tomasz z Akwinu, Summa Theologiae, I, q. 65, a. 2.

Ibidem, I-II, q. 104, a. 4 resp. 
w pionie, o tyle drugi i ostatni - w poziomie zakładającym równość podmiotów wchodzących we wzajemne relacje odnoszące się ad altum.

Społeczeństwo $\mathrm{w}$ doktrynach średniowiecza jest wspólnotą wspólnot, tj. (posługując się językiem matematyki) zbiorem, w skład którego wchodzą takie podzbiory, jak np. rodzina, zakon, stan rycerski, cechy rzemieślnicze. Społeczeństwo stanowi więc organiczną całość złożoną z poszczególnych istnień ludzkich podległych wspólnocie i pełniących wobec niej funkcje służebne. $Z$ jednej strony jednostka nie może odciąć się od społeczeństwa i funkcjonować w pojedynkę, ponieważ jako homo politicus traci rację bytu, a z drugiej w interesie społeczności jest, by jej części składowe stanowiły jedność i przez oddzielanie się nie powodowały uszczerbku dla całości. Z tej wzajemnej zależności rodzi się organiczna jedność ${ }^{8}$. Człowiek jest zatem bytem społecznym zdającym sobie w pełni sprawę, iż jedynie w ramach ludzkiej społeczności może nie tylko istnieć i prawidłowo funkcjonować, ale również wielopłaszczyznowo się doskonalić. Jednocześnie zasady życia zbiorowego wtłaczają jednostkę w określone ramy, wyznaczają jej miejsce w grupie oraz zadania związane z pozycją zawodową i społeczną. Kryterium usytuowania poszczególnych grup społecznych na określonych szczeblach hierarchii wyznacza m.in. podział pracy. Struktura stanowa i zawodowa - gdzie zawód jawi się jako coś na kształt posłannictwa społecznego mającego na celu doskonalenie jednostki - wyraża różnorodność zadań i funkcji społecznych. Podział ogółu politycznej społeczności na stany ma znaczenie ekonomiczne, różnicuje bowiem społeczeństwo pod względem stopy życiowej.

Początkowo hierarchię społeczną Europy łacińskiej przedstawiano w prosty sposób, wyróżniając trzy stany. „Oto, jak z przekąsem skwitowano to w holenderskim powiedzeniu: Modlę się za was, / Ja za was walczę, / A ja składam dla was jaja"".

Z czasem (w XIII w.) wykształcił się stan mieszczański ${ }^{10}$. Podział pracy doprowadził w miastach do wyodrębnienia się dwóch zasadniczych grup: rzemieślników i kupców. Mimo różnic na wielu płaszczyznach między mieszkańcami miast i wsi, mieszczan i chłopów ujmowano w jeden stan zwany plebejskim. Starano się cały czas zachować strukturę trzech stanów społecznych. Wyjaśnienie tego stanu rzeczy znajdziemy w Złotej summie (Summa aurea) Henryka z Suzy, powstałej w latach 1251-1252. Jej autor, odnosząc się do ludzi Kościoła, dowodził, że społeczność ziemska powinna być odbiciem Trójcy Świętej. Stąd podział na trzy stany: ludzi świeckich, duchowieństwo świeckie i duchowieństwo zakonne. „Rdzeniem Kościoła było wyświęcone duchowieństwo zhierarchizowane

8 Koncepcja państwa ujmowanego jako jedność, odwzorowująca ciało człowieka, najpełniej została przedstawiona w doktrynie Jana z Salisbury. Zob. L. Dubel, Wprowadzenie, [w:] Jan z Salisbury, Policraticus albo o paplaninie dworaków i przekazach filozofów, Lublin 2008, s. 22.

9 J.H. Mundy, Europa średniowieczna 1150-1309, Warszawa 2001, s. 157.

10 Ekspansja Kościoła rzymskiego 1054-1274, red. A. Vauchez, Warszawa 2001, s. 351. 
w siedmiu lub ośmiu stopniach. Juryści często wywyższali episkopat jako stopień dziewiąty, przyrównując dziewięć szczebli wojującego Kościoła do dziewięciu anielskich stopni Kościoła triumfującego. Teolodzy jednak nigdy nie zaakceptowali tej idei" ${ }^{11}$. Posłuszeństwo Bogu oznaczało zatem podporządkowanie się porządkowi przez Niego ustanowionemu.

Ponadto hierarchia widoczna jest niezwykle jaskrawo w zależnościach na linii wasal - senior. „Feudalizm nadał tej zależności - jak pisał Grzegorz L. Seidler szczególny patos etyczny, który wykraczał daleko poza uprawnienia i obowiązki stosunku prawnego. Bezwarunkowa lojalność, ślepa wiara i bezgraniczne oddanie wobec seniora - stają się wyidealizowanymi cechami średniowiecznego rycerza" 12 .

W dobie wieków średnich wykształciły się poszczególne zawody, nowe grupy społeczne. Nie można zapominać, że średniowiecze to epoka uniwersytetów. Ich hierarchiczna struktura, tak mocno związana z epoką narodzin, mimo wielu reform i mniej lub bardziej udanych prób demokratyzacji życia akademickiego, nadal jest widoczna.

Na zachowanie ładu społecznego wpływ ma szereg czynników, w tym proces edukacji członków danej społeczności związany z wychowaniem. Jak pisze Feliks W. Bednarski, wychowanie to:

[...] usprawnienie człowieka, a więc jego umysłu, woli i ciała, polega na zdobywaniu i utrwalaniu sprawności zwanych cnotami, gdyż cnota jest to sprawność w dobrym postępowaniu. Jedne $\mathrm{z}$ nich doskonalą nas w stosunku do samego celu ostatecznego, tzn. do Boga; inne zaś w stosunku do środków niezbędnych do jego osiągnięcia ${ }^{13}$.

Średniowieczu zawdzięczamy ,wyodrębnienie grupy ludzi, którzy [...] »parali się słowem i myśląu, nie żyli zaś z dochodów z ziemi ani też nie byli zmuszani "pracować przy użyciu rąk « i którzy, w różnej mierze, świadomi byli tej własnej »odmienności« od pozostałych kategorii ludzkich"14.

Społeczność uniwersytecka składała się z uczniów i nauczycieli, prowadząc bezpośrednio do wykrystalizowania się relacji mistrz - uczeń. Autorytet mistrza był niekwestionowany: decydował o programie, metodach i formach kształcenia. To mistrz na poziomie trivium zapoznawał ,uczniów z regułami wysławiania się, pisania i czytania, wprowadzał ich w świat gramatyki, retoryki i dialektyki [...]. Wiedzę z zakresu arytmetyki, geometrii, muzyki i astronomii zdobywał uczeń w dalszej fazie edukacji, już na poziomie quadrivium" ${ }^{15}$. Każdy uczeń musiał naj-

11 J.H. Mundy, op. cit., s. 192.

12 G.L. Seidler, Myśl polityczna średniowiecza, Kraków 1961, s. 222.

13 F.W. Bednarski, Przedmowa, [w:] Św. Tomasz z Akwinu, Suma teologiczna, t. 20, Londyn 1972, s. 10.

14 M.F.B. Brocchieri, Intelektualista, [w:] Człowiek średniowiecza, s. 232.

15 E. Kotarski, Kultura medialna średniowiecza. Europa łacińska, Warszawa 2017, s. 34. 
pierw odbyć studium septem artes liberales. Następnie mógł - w dalszym etapie pozyskiwania wiedzy - studiować teologię, prawo, medycynę ${ }^{16}$.

Uczeń zdobywał zatem bakalaureat, a następnie licencjat. Po wygłoszeniu pierwszego wykładu otrzymywał tytuł magistra sztuk. Aby nauczać teologii, musiał zdobyć kolejne bakalaureaty: biblijny (baccalarius biblicus), sentencyjny (baccalarius sententiarus), pełny bakałarz (baccalarius formatus). Po zdobyciu wymienionych bakalaureatów, uzyskaniu zgody kanclerza na nauczanie teologii oraz wygłoszeniu pierwszego wykładu (principium) otrzymywał tytuł magistra teologii. Magister posiadający swoją własną katedrę był pełnym profesorem ( $m a$ gister regens $)^{17}$. Z uwagi na ograniczoną do dwunastu liczbę katedr nie każdy magister mógł otrzymać własną.

Kiedy człowiek średniowiecza mówił: mieszczanin, szlachcic, rzemieślnik, rycerz, mistrz czy uczeń - to zawsze miał na myśli mężczyznę. Pisząc o hierarchii jako wyznaczniku ordo wieków średnich, nie można nie odnieść się do „stanu kobiecego". Jak bowiem pisze Christiane Klapisch-Zuber:

[...] ludzie wieków średnich przez dłuższy czas pojmowali „kobiety” jako pewną kategorię - lecz dopiero w późniejszym okresie zostały wprowadzone rozróżnienia w zależności od pozycji społecznej i wykonywanego zawodu [...]. Zanim została chłopką, kasztelanką czy świętą, „kobieta” była definiowana przede wszystkim ze względu na swe ciało, płeć czy stosunki rodzinne.

Biorąc pod uwagę powyższe, należy stwierdzić, że kobieta była córką, siostrą, żoną, matką czy wdową. Jej sytuację społeczną, ekonomiczną i prawną determinowała relacja do mężczyzny: ojca, brata, męża, a nawet syna, któremu winna była posłuszeństwo ${ }^{18}$. W hierarchii społecznej stała więc niżej niż mężczyzna. Tak odczytywano wolę Stwórcy, który z żebra mężczyzny „zbudował niewiastę”19.

W wiekach średnich wykształciło się zatem i umocniło hierarchiczne zróżnicowanie poszczególnych członków społeczności ludzkiej. Koncepcja ordo i wypływające z niej hierarchiczne ujęcia społeczności ludzkiej doprowadziły do zastosowania metafory organizmu ludzkiego do koncepcji państwa ${ }^{20}$. Każdy organizm żywy musi posiadać ośrodek czucia, woli i koordynacji. W ten sposób, dzięki organicznej koncepcji państwa, dochodzimy do kolejnej relacji: rządzący - rządzeni. Władza zwierzchnia, usytuowana najwyżej w hierarchii - na szczycie organizmu (tj. w głowie), ma charakter racjonalny, uwidaczniający się w pełni przy kreowaniu treści norm prawnych; ,[...] rozum króluje poszczególnym

16 Ibidem, s. 37.

17 Z. Kuksewicz, Zarys filozofii średniowiecznej, Warszawa 1979, s. 226.

18 Ch. Klapisch-Zuber, Kobieta i rodzina, [w:] Człowiek średniowiecza, s. 355.

19 Księga Rodzaju 2,22, cyt. za: Pismo Święte Starego i Nowego Testamentu, Poznań 1991, s. 26.

20 Szerzej o koncepcji organistycznej państwa w doktrynie św. Tomasza z Akwinu zob. H.A. Rommen, Die Staatslehre des Franz Suarez JS, Gladbach1926, s. 17-42. 
częściom człowieka"21. Poszczególne jednostki czy grupy są zróżnicowane pod względem ich miejsca w strukturze społecznej. Zgodnie z teorią organiczną tylko harmonijna współpraca gwarantuje prawidłowe funkcjonowanie i rozwój organizmu państwowego. Są bowiem organy czy członki corpus niezbędne do życia, jak serce czy układ pokarmowy, jak również członki, bez których organizm może funkcjonować, mimo że z pewnymi utrudnieniami (nawet w obrębie dłoni palce są zróżnicowane: inną rolę odgrywa palec wskazujący, a inną kciuk, którego brak uniemożliwia chwytanie). Organicyzm zakorzeniony jest w pluralizmie, zasadza się na istnieniu społeczności pośrednich - i to w taki sposób, że społeczności usytuowane na wyższym szczeblu drabiny społecznej niejako zawierają w sobie niższe grupy, gdyż jednocześnie z nich się składają i na nich się opierają. Taka wizja organicyzmu społecznego pokrywa się z wizją społeczeństwa mistycznego.

Tak jak w niebie istnieje zróżnicowanie ciał niebieskich i chórów anielskich, tak na ziemi króluje system feudalny, w którym jednostka ma ustalone miejsce i przypisane jej zadania. Wyznawcy religii chrześcijańskiej stanowią mistyczne ciało Chrystusa na ziemi. Z tą koncepcją koresponduje postulat racjonalności władzy zwierzchniej, której zadaniem ma być dbałość i troska o sprawne funkcjonowanie wszystkich części organizmu, bez względu na ich funkcje. Świadomość konieczności urzeczywistniania w praktyce dnia codziennego koncepcji solidaryzmu społecznego implikuje bonum commune.

Organizm polityczny jawi się u Jana z Salisbury i Tomasza z Akwinu jako fizjologiczna jedność. Owa jedność wymusza określony sposób zorganizowania ${ }^{22}$. Zgodnie z Tomaszową antropologią jednostka jest żywo zainteresowana prawidłowym funkcjonowaniem całości postrzeganej jako corpus. Tomaszowe corpus morale et politicum jest jednocześnie corpus mysticum ${ }^{23}$. W celu zniwelowania różnic i sprzecznych interesów poszczególnych części corpus jednostka angażuje się w sprawy społeczne oraz życie zbiorowości w wymiarze ekonomicznym, politycznym i kulturowym. Czyni to w oparciu o koncepcję dobra wspólnego, które przez swój wkład pracy pragnie urzeczywistnić. Dzięki tego typu działaniom każdej części składowej organizmu politycznego państwo doskonali się i osiąga pełnię samowystarczalności ${ }^{24}$. Praca pro-

${ }_{21}$ Św. Tomasz z Akwinu, De regimine principium (O królowaniu - królowi Cypru), Kraków 2006, 13.3 .

${ }_{22}$ C. Strzeszewski, Hierarchia dobra wspólnego a naturalna hierarchia społeczności, „Roczniki Filozoficzne KUL” 2006, z. 2, s. 5-10.

23 E. Cassirer, Mit państwa, Warszawa 2006, s. 125.

24, „...] wspólnota będzie tym doskonalsza, im bardziej okaże się samowystarczalna w odniesieniu do rzeczy koniecznych do życia. Mamy już do czynienia z pewną samowystarczalnością życiową w jednej rodzinie, zamieszkującej jeden dom - mianowicie w odniesieniu do naturalnych czynności pożywiania się, płodzenia potomstwa itp. W jednej gminie natomiast samowystarczalność odnosi się do wykonywania jednego zawodu. Natomiast we wspólnocie politycznej, która jest wspólnotą doskonałą, mamy do czynienia z samowystarczalnością dotyczącą wszystkiego, co konieczne do życia" - św. Tomasz z Akwinu, De regimine ..., 2.5. 
wadzi do doskonalenia człowieka zarówno w aspekcie jego tężyzny fizycznej, jak i rozwoju duchowego. Dzięki doskonaleniu się człowieka, a w dalszej perspektywie społeczeństwa, zostaje wypracowany system aksjologiczny rzutujący na wychowanie członków danej społeczności.

Człowiek jest zatem częścią wspólnoty, jednym z jej ogniw, bez względu na stopień uspołecznienia (rodzina, gmina, państwo). Jako część składowa większej całości ma moralny obowiązek działania na rzecz jej dobra ${ }^{25}$. Dobro ogółu stanowi zarazem cel nadrzędny i cel pozostający w zgodzie $\mathrm{z}$ dobrem w wymiarze jednostkowym. Dobie średniowiecza obcy był więc indywidualizm we współczesnym rozumieniu. Jednostkę postrzegano jako część społeczeństwa i przez pryzmat grupy patrzono na jej potrzeby, nie negując przy tym godności osoby ludzkiej $^{26}$.

W średniowieczu doszło do wyróżnienia dwóch porządków, oczywiście uporządkowanych względem siebie zgodnie z ordo. Porządek uniwersalny odpowiadał boskiemu dziełu stworzenia świata, natomiast porządek partykularny dotyczył organizacji osobowości rozsądnie działającego człowieka, będącego swoistym „mikrokosmosem”. „Oba porządki pozostają w ścisłej relacji, przy czym uniwersalizm jest swoistym prawzorem wszystkich partykularyzmów. W organizacji państwa porządek uniwersalny znajduje odbicie w osobie i rozumie »chrześcijańskiego« władcy, panującego nad porządkami partykularnymi poddanych" 27 . Porządek uniwersalny miał się tak do partykularnego, jak całość do części. Stąd „dobro wspólnoty ma bardziej boski charakter niż dobro jednego człowieka”"28.

Przyporządkowanie poszczególnych części do całości nie oznacza ubezwłasnowolnienia bytu jednostkowego ani przez społeczność polityczną, ani tym bardziej przez podmiot stojący na jej czele jako zwierzchnik polityczny ${ }^{29}$. Gwarantem poszanowania godności osoby ludzkiej oraz jej indywidualizmu staje się konstrukcja dobra wspólnego. Jest ona tą wartością, która umożliwia człowiekowi życie w dobrze zorganizowanej społeczności ${ }^{30}$. Tym samym stanowi łącznik między etyką a polityką.

${ }^{25}$ Idem, Summa Theologiae, II-II, q. 64, a. 2, a. 5.

26 „Bóg stał się człowiekiem, to po to, aby nas przekonać o godności ludzkiej natury” - ibidem, III, q. 1, a. 2. Por. ibidem, III, q. 3, a. 8.

27 A. Sylwestrzak, Monarchia w traktacie „O królowaniu”, [w:] Kultura i myśl polityczno-prawna. Materiaty z VII Ogólnopolskiego Zjazdu Katedr Doktryn Politycznych i Prawnych Jurata 28-31 maja 2008 r., red. A. Sylwestrzak, D. Szpoper, A. Machnikowska, P. Dąbrowski, Sopot 2010, s. 461.

28 Św. Tomasz z Akwinu, Suma contra gentiles (Summa Filozoficzna), Kraków 1930-1935, III, 17.

29 „Człowiek nie jest przyporządkowany do wspólnoty politycznej całym sobą ani wszystkim tym, co jego" - św. Tomasz z Akwinu, Summa Theologiae, I-II, q. 21, a. 4, ad. 3.

30 P. Śpiewak, W stronę wspólnego dobra, Warszawa 1998, s. 5; M. Novak, Wolne osoby i dobro wspólne, Kraków 1998, s. 37. 
Uświadomienie sobie przez jednostkę korelacji między jej dobrem a dobrem wspólnoty stanowi conditio sine qua non harmonijnego funkcjonowania społeczności. Zachwianie równowagi $\mathrm{w}$ ramach grup interesów prowadzi do zaburzeń w obrębie funkcjonowania wspólnoty: ,[...] jeśli nie do anarchii, to z pewnością do destabilizacji zarówno jednostki, jak i zbiorowości"31.

Dobro wspólne determinuje zatem cele jednostkowe. W interesie pojedynczych bytów leży działanie na rzecz dobra powszechnego. W ten sposób dochodzi do wykształcenia w powszechnej świadomości potrzeby solidarnego działania w imię celu ponadjednostkowego ${ }^{32}$. Konflikt między dobrem osobistym, do którego jednostka dąży w pierwszej kolejności, a dobrem wspólnym jest zdaniem Tomasza z Akwinu pozorny. Kto służy interesowi społecznemu, ten jednocześnie gwarantuje pomyślność dobru osobistemu. Nie można bowiem rozważać problematyki dobra jednostkowego w oderwaniu od zagadnienia dobra mniejszych lub większych społeczności, do których owa jednostka należy: rodziny, gminy czy (w ostatecznym rozrachunku) państwa. Te dwa, pozornie antagonistyczne względem siebie, dobra: jednostki oraz grupy społecznej - warunkują się nawzajem. Ich zakres wzajemnego oddziaływania można określić mianem sprzężenia zwrotnego ${ }^{33}$. Na straży ordo stoi zwierzchnik polityczny, który niwelując rozbieżności teleologiczne dóbr jednostkowych, łącze je w spójnie funkcjonującą, uporządkowaną całość.

„Kto zabiega o dobro wspólne wielu ludzi, w konsekwencji zabiega także o swoje własne dobro" ${ }^{34}$. Jedność dobra wspólnego i dobra jednostkowego należy ujmować przede wszystkim w aspekcie teleologicznym. Różnice między dobrem ogółu a dobrem jednostkowym mają charakter nie tyle ilościowy, co jakościowy. O tożsamości tych dóbr można mówić jedynie, biorąc pod uwagę kryterium celu. Dobra te nie powinny w praktyce życia społeczno-politycznego być sobie przeciwstawione, ponieważ nie dochodzi do procesu ich wzajemnej eliminacji. Dobro sensu largo stanowi sui generis obieg zamknięty: dobro wspólne jest źródłem dobra jednostkowego, ale jednocześnie dobra jednostkowe w nim kończą swój bieg. Nie ma bowiem zdaniem Akwinaty dobra jednostkowego bez dobra rodziny, a dobra rodziny bez dobra szerszej społeczności, jaką stanowi społeczność

31 A. Sylwestrzak, Sprawiedliwość i prawo natury w filozofii Akwinaty, [w:] Moralność i władza jako kategorie myśli politycznej, red. J. Justyński, A. Madej, Warszawa 2011, s. 203.

32 K. Chojnicka, Nauka społeczna Kościoła katolickiego (zarys historii), Kraków 2001, s. 38; Thoma de Aquino, Contra impugnantes Dei cultum et religionem, Romae 1970, s. 8. Por. J. Krucina, Dobro wspólne. Teoria i jej zastosowanie, Wrocław 1972, s. 31.

33 A. Riklin, Die beste Politische Ordnung nach Thomas von Aquin, Sankt Gallen 1991, s. 31-34.

34 Św. Tomasz z Akwinu, Summa Theologiae, II-II, q. 47, a. 10, ad. 2. Tomaszowa koncepcja współgra z Janową: „Publiczne dobro jest zatem takim, które zapewnia spokojne życie zarówno ogólnie, powszechnie, jak i każdemu człowiekowi z osobna” - Jan z Salisbury, Policraticus ..., s. 47. 
państwowa $^{35}$. Dobro jednostki zależy więc od dobra ogółu, a dobro ogółu jest warunkowane dobrem jednostkowym. Współzależność dóbr wymusza współpracę - jednostka działa na rzecz ogółu, ponieważ na konto ogółu działają pozostałe jednostki. Tak zostaje umocnione ordo.

Koncepcja dobra wspólnego jako nadrzędnego celu życia wspólnoty politycznej nie prowadzi do wykształcenia gromady, której poszczególni członkowie zatracają swoją indywidualnośćc ${ }^{36}$. Człowiek nie zostaje pozbawiony możliwości decydowania o sobie, podejmowania decyzji dotyczących swojego miejsca w grupie i stosowania się do zasad preferowanych przez ogół. Ów rys indywidualizmu prowadzi do Tomaszowego personalizmu konstruowanego na fundamencie rozumnej ludzkiej natury. Człowiek jest narzędziem jedynie w ręku Boga, swojego Stwórcy. Poza tym jest wolnym podmiotem w sensie potencjalności wyboru. Tomaszowy personalizm, który mówi o tym, że człowiek tym różni się od zwierząt potrafiących rozróżniać co dla nich dobre, a co złe, iż ma rozum pozwalający mu na analizowanie wszelkich okoliczności w celu świadomego i dobrowolnego wyboru optymalnego rozwiązania. Człowiek nie jest - w przeciwieństwie do doktryn starożytności - ujmowany ,jako jedynie egzemplarz gatunku ludzkiego. Jego cele nie są wyznaczone tylko gatunkowo - wspólnym wszystkim ludziom człowieczeństwem (istotą ludzką), ale i indywidualnie, i nie tylko ze względu na przypadkowe cechy (przypadłości) i okoliczności działania"37.

$\mathrm{Z}$ pojęciami ordo oraz bonum commune ściśle wiąże się problematyka pax $^{38}$. Pojęcie pokoju, tak jak porządku, zostało zapożyczone z doktryny augustiańskiej. Pod terminem pax należy rozumieć pokój w sensie posłuszeństwa poddanych nakazom suwerena (pokój wewnętrzny) oraz zgodnego wspólistnienia między państwami (pokój zewnętrzny) ${ }^{39}$. Zatem pax to ,porządek życia społecznego oparty na sprawiedliwości" ${ }^{40}$. Prowadzi on bezpośrednio do zachowania ordo. Jedność społeczności państwowej nie jest jednością per se, lecz secundum quid, czyli pod pewnym względem. Ma charakter przypadłościowy, stanowiąc unitas ordinis.

35 Św. Tomasz z Akwinu, Summa Theologiae, II-II, q. 26, a. 3; ScG., I, 4; III, 17.

36 Por. ibidem, II-II, q. 64, a. 2, ad. 3. Józef Majka (Katolicka nauka społeczna, Warszawa 1988, s. 132-133) obliczył, że Tomasz 60 razy powtórzył na kartach swoich dzieł tezę o wyższości dobra ogółu nad dobrem jednostkowym (przy czym należy nadmienić, że Tomasz zastrzegał hierarchię dóbr i celów).

37 M. Piechowiak, Tomasza z Akwinu koncepcja godności osoby ludzkiej jako podstawy prawa. Komentarz do rozdziałów 111-113 księgi III Tomasza z Akwinu Suma contra gentiles, „Poznańskie Studia Teologiczne" 2003, t. 14, s. 219-242.

38 Por. S. Kowalczyk, Filozofia pokoju św. Augustyna, „Vox Patrum” 1988, z. 15, s. 833; idem, Filozofia pokoju św. Tomasza z Akwinu, „Roczniki Nauk Społecznych” 1988-1989, t. 16-17, s. $70-71$.

39 T. Szczech, Państwo i prawo w doktrynie św. Augustyna, Marcina Lutra i Jana Kalwina, Łódź 2006, s. 111-112.

40 M. Sadowski, op. cit., s. 89. 
Owa jedność porządku (uintas compositionis) uczestniczy przez pax w bonum commune. Każdy członek społeczności jest bowiem podporządkowany celowi zasadniczemu.

Pożądanie, którego celem jest dobro, pokój i piękno, nie posiada wielu kresów, bo z tego względu, że coś pożąda dobra, pożąda także piękna i pokoju. [...] Pokój natomiast zakłada usunięcie przeszkód w zdobyciu dobra. Z tego zaś powodu, że coś jest pożądane, pożądane jest również usunięcie jego przeszkód. Dlatego w tym samym pożądaniu pragniemy jednocześnie dobra, piękna i pokoju ${ }^{41}$.

Zróżnicowanie członków wspólnoty politycznej dotyczy funkcji społecznych wyznaczających jednostce miejsce w ramach grupy społecznej. Pozostawanie jednostki na właściwym dla niej miejscu oraz sumienne wywiązywanie się z przyjętych na siebie obowiązków jest gwarantem porządku społecznego. Ordo jest zakorzenione w hierarchii, ponieważ zasadza się na uporządkowaniu bytów w kolejności określonej stopniami (gradus) drabiny społecznej. Pozostawanie każdego na wyznaczonym mu miejscu - parafrazując słowa św. Augustyna - stanowi mediewistyczne conditio sine qua non ładu, bezpieczeństwa i spokoju społecznego.

\section{BIBLIOGRAFIA}

Bednarski F.W., Przedmowa, [w:] Św. Tomasz z Akwinu, Suma teologiczna, t. 20, Londyn 1972. Brocchieri M.F.B., Intelektualista, [w:] Człowiek średniowiecza, red. J. Le Goff, Warszawa 2000. Cassirer E., Mit państwa, Warszawa 2006.

Chojnicka K., Nauka społeczna Kościoła katolickiego (zarys historii), Kraków 2001.

Dubel L., Wprowadzenie, [w:] Jan z Salisbury, Policraticus albo o paplaninie dworaków i przekazach filozofów, Lublin 2008.

Ekspansja Kościoła rzymskiego 1054-1274, red. A. Vauchez, Warszawa 2001.

Jan z Salisbury, Policraticus albo o paplaninie dworaków i przekazach filozofów, Lublin 2008.

Klapisch-Zuber Ch., Kobieta i rodzina, [w:] Człowiek średniowiecza, red. J. Le Goff, Warszawa 2000.

Kornatowski W., Społeczno-polityczna myśl św. Augustyna, Warszawa 1965.

Kotarski E., Kultura medialna średniowiecza. Europa łacińska, Warszawa 2017.

Kowalczyk S., Filozofia pokoju św. Augustyna, „Vox Patrum” 1988, z. 15.

Kowalczyk S., Filozofia pokoju św. Tomasza z Akwinu, „Roczniki Nauk Społecznych” 1988-1989, t. $16-17$.

Krucina J., Dobro wspólne. Teoria i jej zastosowanie, Wrocław 1972.

Kuksewicz Z., Zarys filozofii średniowiecznej, Warszawa 1979.

Le Goff J., Człowiek średniowiecza, [w:] Człowiek średniowiecza, red. J. Le Goff, Warszawa 2000.

Majka J., Katolicka nauka społeczna, Warszawa 1988.

Mundy J.H., Europa średniowieczna 1150-1309, Warszawa 2001.

Novak M., Wolne osoby i dobro wspólne, Kraków 1998.

Piechowiak M., Tomasza z Akwinu koncepcja godności osoby ludzkiej jako podstawy prawa. Komentarz do rozdziałów 111-113 księgi III Tomasza z Akwinu Suma contra gentiles, „Poznańskie Studia Teologiczne" 2003, t. 14.

${ }^{41}$ De verit., q. 22, q. 1, ad. 12. 
Pismo Święte Starego i Nowego Testamentu, Poznań 1991.

Riklin A., Die beste Politische Ordnung nach Thomas von Aquin, Sankt Gallen 1991.

Rommen H.A., Die Staatslehre des Franz Suarez JS, Gladbach1926.

Sadowski M., Godność człowieka i dobro wspólne w papieskim nauczaniu społecznym (1878-2005), Wrocław 2010.

Seidler G.L., Myśl polityczna średniowiecza, Kraków 1961.

Strzeszewski C., Hierarchia dobra wspólnego a naturalna hierarchia społeczności, „Roczniki Filozoficzne KUL" 2006, z. 2.

Sylwestrzak A., Monarchia w traktacie „O królowaniu”, [w:] Kultura i myśl polityczno-prawna. Materiaty z VII Ogólnopolskiego Zjazdu Katedr Doktryn Politycznych i Prawnych Jurata 28-31 maja 2008 r., red. A. Sylwestrzak, D. Szpoper, A. Machnikowska, P. Dąbrowski, Sopot 2010.

Sylwestrzak A., Sprawiedliwość i prawo natury w filozofii Akwinaty, [w:] Moralność i wladza jako kategorie myśli politycznej, red. J. Justyński, A. Madej, Warszawa 2011.

Szczech T., Państwo i prawo w doktrynie św. Augustyna, Marcina Lutra i Jana Kalwina, Łódź 2006.

Śpiewak P., W stronę wspólnego dobra, Warszawa 1998.

Św. Augustyn, Państwo Boże, Kęty 1999.

Św. Tomasz z Akwinu, De regimine principium (O królowaniu - królowi Cypru), Kraków 2006.

Św. Tomasz z Akwinu, Suma contra gentiles (Summa Filozoficzna), Kraków 1930-1935.

Thoma de Aquino, Contra impugnantes Dei cultum et religionem, Romae 1970.

Thoma de Aquino, Summa Theologiae, Romae 1892.

\section{SUMMARY}

Order and hierarchy are the basic elements of Medieval thought. The guarantor of social order is an individual at the right place and fulfilling their duties diligently. Ordo is rooted in hierarchy and it means that individuals are put in a particular order of a social ladder expressed in grades (gradus). Everyone should stay at the right place - paraphrasing Saint Augustin - it is a Medieval conditio sine qua non of safety and social order. According to the author, the problem of ordo is formed on two tracks: a status gradation conditioned by the division of labour and as ordo universalis, which means order directly leading to an individual hierarchy created by God.

Keywords: Middle Ages; hierarchy; social order

\section{STRESZCZENIE}

Porządek i hierarchia są podstawowymi elementami myśli średniowiecznej. Pozostawanie jednostki na właściwym dla niej miejscu i sumienne wywiązywanie się z przyjętych na siebie obowiązków jest zatem gwarantem porządku społecznego. Ordo zakorzenione jest w hierarchii, zasadza się bowiem na uporządkowaniu bytów w kolejności określonej stopniami (gradus) drabiny społecznej. Pozostawanie każdego na wyznaczonym mu miejscu - parafrazując słowa św. Augustyna - stanowi mediewistyczne conditio sine qua non ładu, bezpieczeństwa i spokoju społecznego. Zdaniem autorki problematyka ordo kształtuje się dwutorowo: jako gradacja stanowa uwarunkowana głównie podziałem pracy oraz jako ordo universalis, czyli porządkiem jako takim, uporządkowaniem prowadzącym wprost do hierarchii bytów stworzonych przez Boga.

Słowa kluczowe: średniowiecze; hierarchia; porządek społeczny 